\title{
Knowledge and Practice of Self-medication among Students of School of Nursing in selected schools in Osun State
}

\author{
Article by Abioye Abigail Adebisi \\ $B S N-M S N$ in Nursing, Texila American University, Nigeria \\ E-mail: sundayabioye@gmail.com
}

\begin{abstract}
Self-medication can potentially do well and also harm people. It is a common practice and internationally has been reported as being on the rise. Studies have observed self-medication as a common practice among group of health workers that included dental, midwifery and nursing students. Hence, this study assessed the knowledge and practice of self-medication among students of school of nursing in selected schools in Osun State. It was a descriptive cross-sectional survey. Samples of two hundred nursing students were included in the study using purposive sampling.

The result in this study showed that majority (91\%) of the nursing students had high level of knowledge and about two third (64.5\%) indulge in high practice of self medication respectively. More than half of them signified that presence of minor ailments and having enough knowledge about drugs were the factors that always make them to self-medicate, while more than forty percent indicated that financial constraint, previous experience, time saving, advertisement and unavailability of health care services as factors that sometimes influence self-medication. Significant relationship existed between knowledge and practice of self medication $(t=-3.116, d f=198, P<0.05)$.

Nursing students demonstrated high level of knowledge about medication and its effects. Majority indulge in self-medication practices. Those with high level of knowledge practice of self medication less. It would be safer if those who self-medicate have sufficient knowledge to prevent serious effects. It is recommended that policies be formulated to control the purchase and use drugs.
\end{abstract}

Keywords: Practices of self-medication among nursing students

\section{Introduction}

Self -medication is a common practice and internationally has been reported as being on rise and can produce a good result and be a convenient practice for patient (Verma, Mohan and Pandey, 2010). It was observed that self-medication is a common practice among group of health workers that included dental, midwifery and nursing students (Ehigiator, Azodo, Ehizele, Ezeja, and Ehigiator et al, 2013). In Nigeria, high degree of irresponsible selfmedication is practised (Olayemi, Olayinka and Musa, 2010).

Self-medication can potentially do well and also harm people. This is especially significant in those countries where prescription drugs are available over-the-counter (OTC) due to lack of enforcement of regulations (Sontakke, Bajait, Pimpalkhute, and Jaiswal, 2011). The increase in the quantities and varieties of pharmaceuticals worldwide eases the accessibility of medicine by consumers, thereby giving options for its misuse (Ehigiator, et al 2013). Recent development of the pharmaceutical companies contribute to a wide spread availability of OTC Medicine. There is also the potential for misuse and abuse of such products (Ali, Ibrahim and Palaian, 2010). Its irrational use increases the risk of adverse effects, bacterial infection, hypersensitivity, drug withdrawal symptom and of masking disease which can delay correct diagnosis (Bernal and Silva, 2010).

The common sources of self-medication are previous prescription, friends, advertisements, chemist shop and books (Joshi, Shalini and Agarwal, 2011). Self-medication is influenced by many factors such as education, family, society, law, availability of drugs and exposure to 
advertisements (Vizhi and Senapathi, 2010). Modern consumers (patients) wish to take a greater role in the maintenance of their own health and are often competent to manage (uncomplicated) chronic and recurrent illnesses (not merely short-term symptoms) after proper medical diagnosis and with only occasional professional advice. They are understandably unwilling to submit to the inconvenience of visiting a doctor for what they rightly feel they can manage for themselves, given adequate information (Vizhi and Senapathi, 2010).

Inappropriate self-medication results in wastage of resources, increased resistance of pathogens to drugs, and generally entails serious health hazards such as adverse reactions and prolonged hospitalization. Self-medication among future health care professionals can represent a serious threat to professionalism in medicine and it has potential to put at risk public trust into this profession (Lukovic, Miletic, Pekmezovic, Trajkovic, Ratkovic, et al, 2014). In Nigeria, high degree of irresponsible self-medication is practised (Olayemi, Olayinka and Musa, 2010).

The practice of self-medication among students seems to be on the increase. Dimabayao and Mohammad (2016) found the prevalence of self-medication practice among nursing students in Jazan University, Kingdom of Saudi Arabia to be $43 \%$. There has been an increasing tendency of self medication behaviour among various health sciences graduates and students including doctors, pharmacists and nurses in different regions of the world (Banerjee and Bhadury, 2012).

Some of the problems associated with self-medication such as masked diagnoses, use of excessive drug dosage, prolonged duration of use, drug interactions, polypharmacy and superinfection can occur in self-medicating individuals. A number of reasons have been adduced for the rise of self-medication among students. This study would help the researcher to picture the pattern of self-medication among nursing students, identify multiple factors associated with self-medications.

Hence the reason for this study is due to high rise of self medication in the society. The nursing students just like any other students in medical line are conversant with drugs and have basic knowledge of pharmacology. This study explored the knowledge and practise of self medication among nursing students in selected schools of nursing in Osun State.

Responsible self-medication entails using approved and available medicine in a safe and effective way as directed though without prescription (WHO, 2014). The types of drugs used are indicated for a self-recognisable condition following initial medical diagnosis, which means that users have previous knowledge of the dose, time and side effect(s) of the overdose of the drug. Responsible self-medication is possible in the developed nations because of high quality of education, accessibility to health information, safety and quality health care including government policies on health coupled with the health-seeking behaviour and sceptical expert knowledge (Talevi, 2010).

Responsible self-medication is the use of a registered or mono-graphed medicine legally available without a physician's prescription, either on an individual's own initiative or following advice of a healthcare professional. The use of prescription medicines without a prior medical prescription is not part of responsible self-medication. The safety, efficacy and quality of non-prescription medicines must be proved according to the same principles as prescription medicines (WMA, 2012).

Non-responsible self-medication is the use of drugs in the treatment of self-diagnosed ailments or symptoms of diseases without supervision or prescription by a physician (Ruiz, 2010). It is characterised by indiscriminate use of drugs for the management of ailments many of which have resulted into intoxication (Galato, Galafassi, Alano and Trauthman, 2009). Major problem of non-responsible self-medication is the lack of clinical evaluation by a medical professional which can result into wrong diagnosis and delay in appropriate treatment, drug resistance, use of expired drugs, wrong doses and prolonged duration of usage. For an individual to self-medicate appropriately, he must be able to accurately recognize symptoms, set therapeutic objectives, select appropriate medicine to be used for his 
medical condition, and determine appropriate dosage and dosage schedule taking into account his medical history, contraindication and possible side effects of the medicine. This would therefore require adequate knowledge about medicines (Auta, Shalkur, Omale and Abiodun, 2012).

The factors influencing self-medication remains issues of intense debate in academic discourse (Osemene and Lamikara, 2012). Availability of drugs in markets and poor drug regulatory practices (Fadare and Tamuno, 2011) contribute to self-medication. Many Nigerians, most times, trivialize ailments such as headache, fever, cough, throat infection, common cold and stomach ache (Emmanuel, Daniel, Achema, Afor, Onyejekwe and Gimba, 2011). Other factors like demographic factors have been found to influence self-medication. For instance, gender, age, sex and social role were discovered to have influence on selfmedication (Osemene and Lamikara, 2012). Some studies revealed higher prevalence of selfmedication among males than females (Al-Hussaini, Mustafa and Ali, 2014) while some scholars found no strong association between gender (Emmanuel, et al, 2011). On the other hand, a high level of education and professional status of mothers are showed to be risk factors for adolescent self-medication in some studies (Awosusi et al, 2015).

According to Dimabayao and Mohammad (2016), social, financial and health related factors drive the use of medications. Some factors why individuals practice self-medication include geographical difficulties in accessing health care centres and unavailability of qualified medical doctors. El-Nimr, Wahdan, Kotb and Wahdan (2015) adduced the reason for practicing self medication was that it is less expensive compared to medical care in the hospital. The fact remains that many rural communities have little or no access to modern medical care because of the uneven distribution or inadequate health facilities (Arikpo, Eja and Enyi-Idoh, 2009). This may encourage the practice of self- medication.

Several factors including poverty, cultural perception of certain diseases' entity and their perceived responses to indigenous medications have been widely reported as indicators in developing countries making the practice a necessity (Shah, Parmar, Kumkishan and Mehta, 2011). This makes it more dangerous as basic knowledge concerning the pharmacological properties of these substances/ drugs may be lacking. Improvements in people's general knowledge, level of education and socioeconomic status in many countries form a reasonable basis for successful self-medication. Several factors could affect the self medication practice and that includes sex, age, and race, educational \&economic status (Albalawi, Al-Anazi, Althamali Alzhahrani and Aloqbi, 2015).

\section{Methodology}

The study adopted a cross-sectional descriptive design. The study settings were School of Nursing, OAUTHC, Ile-Ife and School of Nursing, Wesley Guild Hospital, Ilesa, Osun-State. The target population were student nurses in the selected schools of nursing, total number of two hundred students. Purposive sampling technique was adopted in this study as only students in 200level and 300level formed the sample size.

The instrument for data collection was a self-structured questionnaire. The instrument has four sections. Section A sought the socio-demographic data. Section B assesses the knowledge of the students about self-medication. Section $C$ determines the practices of selfmedication among students, while Section D identifies factors influencing self-medication among students. Questionnaires were administered hand to hand for four days.

The data collected was analyzed using Statistical package of social sciences (SPSS), version 20. The research questions were censored using a descriptive analysis like percentages, frequencies and tables where applicable.

In determining the level of knowledge of respondents on self-medication, each correct answer to the 11-item questions in table 2 above were scored 1 . All the questions were summed together and the highest possible score was 11 . The median score is 6 . Scores above the median score are categorized as Good knowledge about medicines and effects of self medication, while scores below had poor knowledge. In determining the level of practice of 
Texila International Journal of Public Health

Volume 4, Issue 4, Dec 2016

self medication among respondents, each correct answer in the 8-item questions in table 3 above were awarded 1mark. All the questions were summed together and the median score was 4 and the highest possible score was 8 . Scores above the median score are said to have high level practice of self medication, while scores below had low level practice of self medication.

\section{Results}

Completely filled two hundred questionnaires were used for the analysis.

Table 1. Socio-demographic Data of the Respondents $(n=200)$

\begin{tabular}{|c|c|c|c|}
\hline Variables & & Frequency & Percent \\
\hline \multirow{3}{*}{$\begin{array}{l}\text { Age group in years: } \\
\text { Mean }=21.57, S D=3.08 \\
\text { Min }=18, \text { Max }=38, \text { Range }=20\end{array}$} & $10-19$ & 25 & 12.5 \\
\hline & $20-29$ & 167 & 83.5 \\
\hline & $30-39$ & 8 & 4.0 \\
\hline \multirow{2}{*}{ Ethnicity } & Yoruba & 191 & 95.5 \\
\hline & Igbo & 9 & 4.5 \\
\hline \multirow{2}{*}{ Gender } & Male & 26 & 13.9 \\
\hline & Female & 174 & 87.0 \\
\hline \multirow{2}{*}{ Religion } & Christianity & 137 & 68.5 \\
\hline & Islam & 63 & 31.5 \\
\hline \multirow{2}{*}{ Level of education } & 200 Level & 50 & 50.0 \\
\hline & 300 Level & 50 & 50.0 \\
\hline \multirow{6}{*}{$\begin{array}{l}\text { Position in the family (number) e.g. } \\
1,2,3 \text { : }\end{array}$} & 1 & 61 & 30.5 \\
\hline & 2 & 59 & 29.5 \\
\hline & 3 & 40 & 20.0 \\
\hline & 4 & 14 & 7.0 \\
\hline & 5 & 15 & 7.5 \\
\hline & $>5$ & 11 & 5.5 \\
\hline \multirow{5}{*}{ Number of children in the family } & 1 & 6 & 1.6 \\
\hline & 2 & 28 & 7.5 \\
\hline & 3 & 86 & 23.0 \\
\hline & 4 & 133 & 35.6 \\
\hline & $\begin{array}{l}\text { More than } 4 \\
\text { children }\end{array}$ & 121 & 32.4 \\
\hline
\end{tabular}

Table 1 above showed that the mean age and the standard deviation of the respondents were $21.57 \pm 3.08$. Majority (83.5\%) of the respondents were within ages $20-29$ years, almost all (95.5\%) were Yoruba and majority (87.0\%) were females. About two-third (68.5\%) were Christians and just half (50.0\%) of them were in the 200 level. 
Table 2. Knowledge about Medicines and effects of self-medication

\begin{tabular}{|l|l|l|l|}
\hline Knowledge Questions & $\begin{array}{l}\text { Agreed n } \\
(\mathbf{\%})\end{array}$ & $\begin{array}{l}\text { Uncertain } \\
\mathbf{n}(\%)\end{array}$ & $\begin{array}{l}\text { Disagree } \\
\mathbf{n}(\mathbf{\%})\end{array}$ \\
\hline $\begin{array}{l}\text { Self-medication can have harmful effects on one's } \\
\text { health }\end{array}$ & $194(97.0)$ & $4(2.0)$ & $2(1.0)$ \\
\hline Self-medication can lead to substance abuse & $192(96.0)$ & $6(3.0)$ & $2(1.0)$ \\
\hline $\begin{array}{l}\text { It is good to combine traditional medicine with } \\
\text { western medicine }\end{array}$ & $16(8.0)$ & $30(15.0)$ & $154(77.0)$ \\
\hline Antibiotics are needed for common cold & $78(39.0)$ & $29(14.5)$ & $93(46.5)$ \\
\hline $\begin{array}{l}\text { One can use the same drug for similar ailment } \\
\text { anytime }\end{array}$ & $28(14.0)$ & $23(11.5)$ & $140(74.5)$ \\
\hline $\begin{array}{l}\text { You can stop treatment as soon as the symptoms } \\
\text { had disappeared }\end{array}$ & $30(15.0)$ & $18(9.0)$ & $152(76.0)$ \\
\hline $\begin{array}{l}\text { One can take many types of antibiotics at the } \\
\text { same time during the course of a single illness }\end{array}$ & $42(21.0)$ & $19(9.5)$ & $139(69.5)$ \\
\hline $\begin{array}{l}\text { There is no big deal if one skips or forget to take } \\
\text { his antibiotic drugs }\end{array}$ & $16(8.0)$ & $25(12.5)$ & $159(79.5)$ \\
\hline $\begin{array}{l}\text { Overuse of some drugs can result in drug } \\
\text { resistance }\end{array}$ & $188(94.0)$ & $6(3.0)$ & $6(3.0)$ \\
\hline Antibiotics can be effective for viral infections & $72(36.0)$ & $28(14.0)$ & $100(50.0)$ \\
\hline $\begin{array}{l}\text { Expensive drugs are more effective and have less } \\
\text { side effects }\end{array}$ & $54(27.0)$ & $50(25.0)$ & $96(48.0)$ \\
\hline
\end{tabular}

In table 2 above, almost all (97\%) the respondents agreed that self-medication can have harmful effects on people's health, $96 \%$ also indicated that it leads to substance abuse, and $94 \%$ agreed that over use of some drugs can result in drug resistance. About three-quarter (77\%) respectively disagreed that it is good to combine traditional medicine with western medicine, $74.5 \%$ disagreed that one can use the same drug for similar ailment anytime, $76 \%$ opposed that one can stop treatment as soon as the symptoms had disappeared and $79.5 \%$ also opposed that there is no big deal if one skips or forget to take his antibiotic drugs. About twothird (69.5\%) opposed that one can take many types of antibiotics at the same time during the course of a single illness, half of them disagreed that antibiotics can be effective for viral infections. Furthermore, larger percentage (48\%) respectively opposed that expensive drugs are more effective and have less side effects, and $46.5 \%$ disagreed that antibiotics are needed for common cold.

Table 2.1. Summary of Knowledge about Medicines and effects of self-medication

\begin{tabular}{|l|c|c|c|c|}
\hline $\begin{array}{l}\text { Level of } \\
\text { Knowledge }\end{array}$ & Frequency Percent & Median Score & Max Possible Score \\
\hline Poor Level & 18 & 9.0 & 6 & 11 \\
\hline Good Level & 182 & 91.0 & & \\
\hline Total & 200 & 100.0 & & \\
\hline
\end{tabular}

In determining the level of knowledge of respondents on self-medication, each correct answer to the 11-item questions in table 2 above were scored 1 . All the questions were summed together and the highest possible score was 11 . The median score is 6 . Scores above the median score are categorized as Good knowledge about medicines and effects of self medication, while scores below had poor knowledge. Table 2.1 showed that about almost all (91\%) of the respondents had good knowledge about medicines and effects of self medication, while $9 \%$ had poor knowledge. 


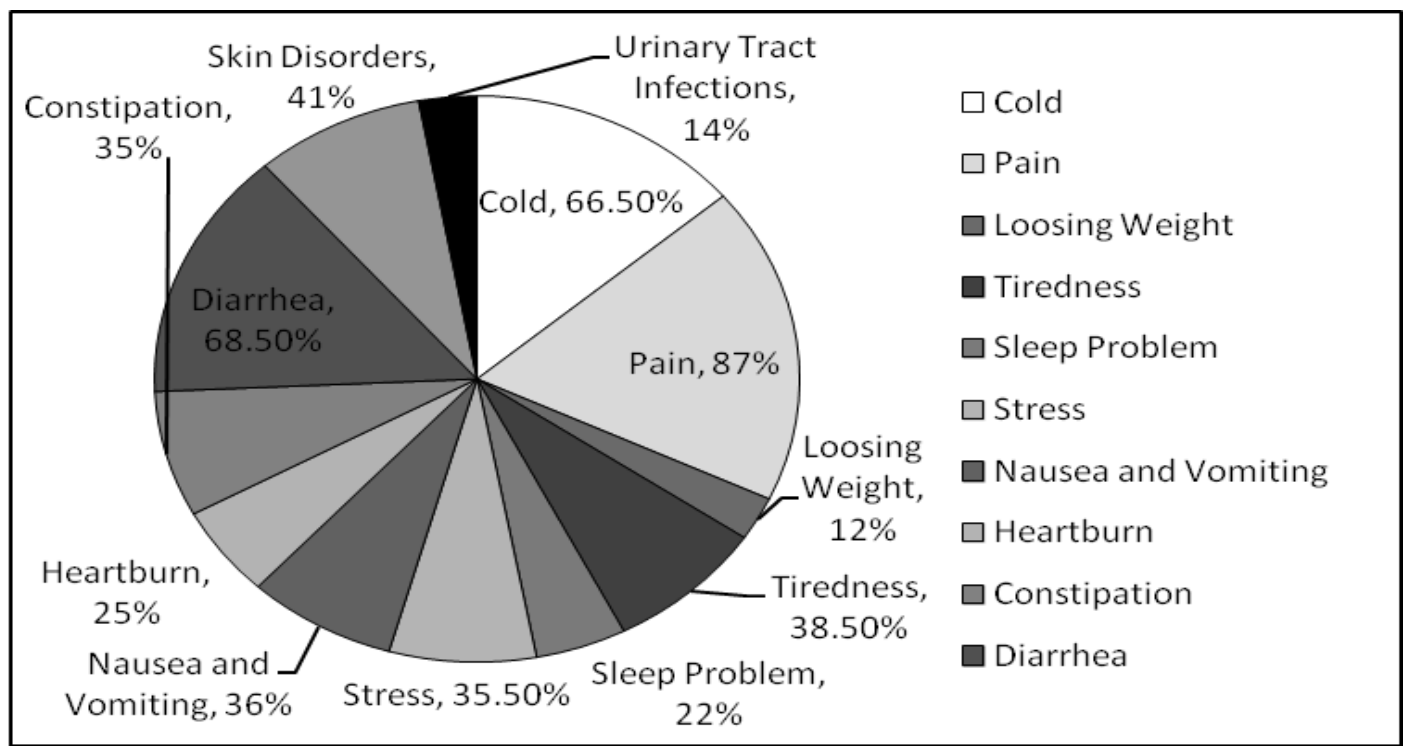

Figure 1. Factors Influencing the Use of Self-medication

The figure above showed that majority of the respondents have self-medicated for the following conditions; pain (87\%), diarrhoea (68.5\%) and cold (66.5\%).

Table 3. Practice of Self-medication

\begin{tabular}{|l|l|l|}
\hline Variables & Yes n (\%) & No n (\%) \\
\hline $\begin{array}{l}\text { Apart from treatment(s) prescribed by your practitioner, do } \\
\text { you sometimes take medicine to treat yourself? }\end{array}$ & $168(83.0)$ & $32(16.0)$ \\
\hline $\begin{array}{l}\text { Do you reuse the prescription when experienced with similar } \\
\text { symptoms? }\end{array}$ & $125(62.5)$ & $75(37.5)$ \\
\hline $\begin{array}{l}\text { Do you increase the drug dose on yourself when symptoms } \\
\text { are not relieved? }\end{array}$ & $27(13.5)$ & $173(86.5)$ \\
\hline $\begin{array}{l}\text { Do you discontinue the medicines by yourself when } \\
\text { symptoms are relieved? }\end{array}$ & $109(54.5)$ & $91(45.5)$ \\
\hline $\begin{array}{l}\text { Do you give your prescription/drugs to someone who is } \\
\text { having similar symptoms as yours before }\end{array}$ & $87(43.5)$ & $113(56.5)$ \\
\hline Do you combine herbal medicine and western medicine & $28(14.0)$ & $172(86.0)$ \\
\hline $\begin{array}{l}\text { I normally check the labels in my drug pack before using } \\
\text { them }\end{array}$ & $176(88.0)$ & $24(12.0)$ \\
\hline $\begin{array}{l}\text { I am willing to practice self-medication whenever the need } \\
\text { arises }\end{array}$ & $106(53.0)$ & $94(47.0)$ \\
\hline
\end{tabular}

Table 3 above showed the practice of self-medication among the respondents. Majority (83\%) of them indicated they sometimes take medicines not prescribed by the practitioners to treat themselves. Also, about two-third (62.5\%) signified they do reuse the prescription when they experience similar symptoms, however majority (86.5\%) do not increase the drug dose on themselves when symptoms are not relieved. A little over half (54.5\%) indicated they do discontinue the medicines by themselves when symptoms are relieved. More than half (56.5\%) of them do not give their prescription/drugs to someone who is having similar symptoms as the ones they once had. Majority $(86 \%, 88 \%)$ of them do not combine herbal with western medicine; normally check the labels in their drug packs before usage respectively. Over half (53\%) submitted that they are willing to practice self-medication whenever the need arises. 
Table 3.1. Summary of Practice of Self-medication among Respondents

\begin{tabular}{|l|l|l|l|l|}
\hline Level of Practice & Frequency & Percent & Median & Max Score \\
\hline Low Level & 71 & 35.5 & 4 & 8 \\
\hline High Level & 129 & 64.5 & & \\
\hline Total & 200 & 100.0 & & \\
\hline
\end{tabular}

In determining the level of practice of self medication among respondents, each correct answer in the 8-item questions in table 3 above were awarded 1mark. All the questions were summed together and the median score was 4 and the highest possible score was 8 . Scores above the median score are said to have high level practice of self medication, while scores below had low level practice of self medication.

Table 3.1 showed that about two-third (64.5\%) of the respondents had high level of practice of self medication, while a third had low level of knowledge about it.

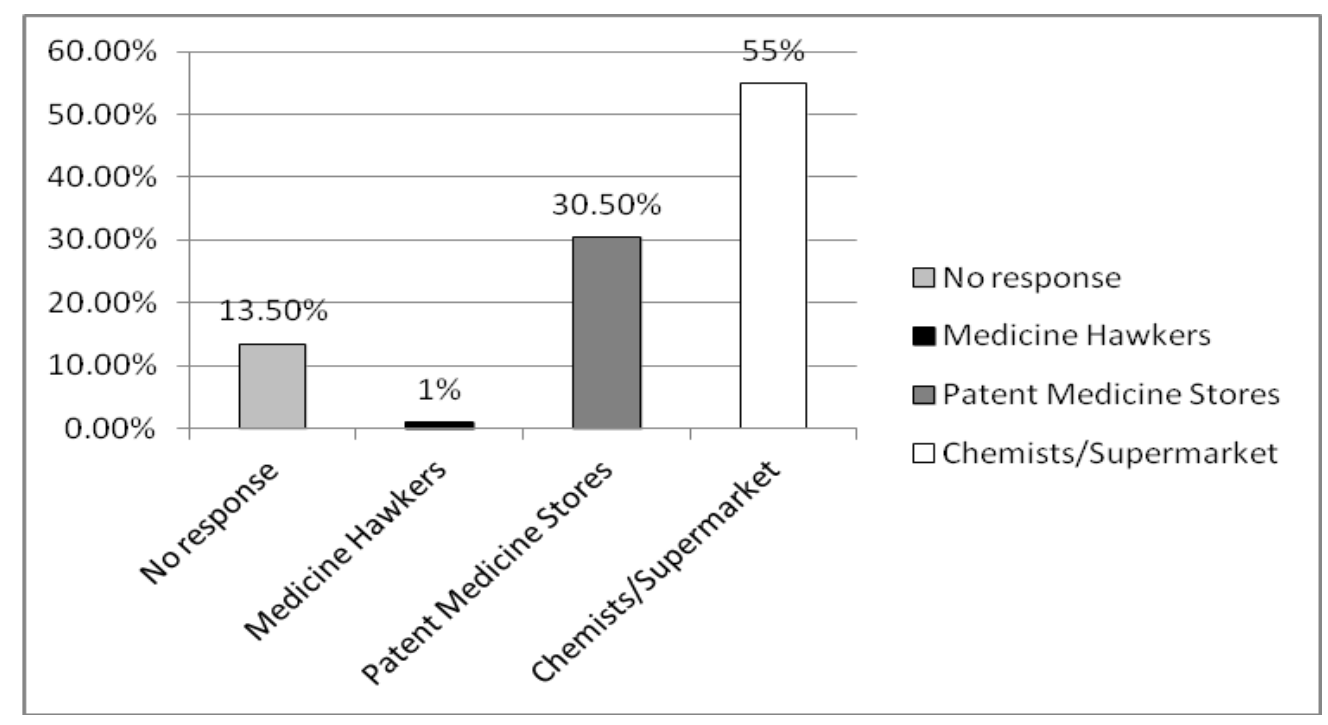

Figure 2. Preferred place to get the un-prescribed drug

The figure above showed the preferred place for respondents to get un-prescribed drugs. More than half (57.2\%) preferred chemist/ supermarket to get their non-prescribed drugs, while about a third do get it from patent medicine stores.

Table 4. Reasons/Factors Influencing Self-medication

\begin{tabular}{|l|l|l|l|}
\hline Variables & Always & Sometimes & Never \\
\hline Minor ailment & $103(51.5 \%)$ & $81(40.5 \%)$ & $16(8.0 \%)$ \\
\hline Financial constraint & $66(33.0 \%)$ & $94(47.0 \%)$ & $40(20.0 \%)$ \\
\hline Enough knowledge & $108(54.0 \%)$ & $78(39.0 \%)$ & $14(7.0 \%)$ \\
\hline Previous experience & $97(48.5 \%)$ & $93(46.5 \%)$ & $10(5.0 \%)$ \\
\hline Time saving & $75(37.5 \%)$ & $94(47.0 \%)$ & $31(15.5 \%)$ \\
\hline Health care services not available & $45(22.5 \%)$ & $93(46.5 \%)$ & $62(31.0 \%)$ \\
\hline $\begin{array}{l}\text { Lack of support from friends and } \\
\text { family }\end{array}$ & $34(17.0 \%)$ & $78(39.0 \%)$ & $88(44.0 \%)$ \\
\hline Ignorance & $79(39.5 \%)$ & $48(24.0 \%)$ & $73(36.5 \%)$ \\
\hline Advertisement & $55(27.5 \%)$ & $86(43.0 \%)$ & $59(29.5 \%)$ \\
\hline
\end{tabular}

Table 4 above depicts the reasons or factors influencing self medication among respondents. Just half (51.5\%, 54\% and 48.5\%) of the respondents signified they always see the presence of minor ailments, having enough knowledge about drugs and previous experience as a reasons for self-medication. Larger percentage (47\%, $46.5 \%$ and $43 \%)$ of them respectively indicated that financial constraints, time saving and advertisement 
Texila International Journal of Public Health

Volume 4, Issue 4, Dec 2016

sometimes influence self-medication. More than one-third (38.8\%) indicated ignorance can always influence it.

Table 5. Relationship between the knowledge about effects of self medication and practice of self medication among respondents

\begin{tabular}{|l|l|l|l|l|l|l|l|}
\hline Variables & Knowledge & $\mathrm{N}$ & Mean & Std. Dev & $\mathrm{t}$ & df & Sig. (2-tailed) \\
\hline \multirow{2}{*}{ Practice } & High & 181 & 4.0387 & 1.67784 & -2.226 & 198 & .027 \\
\cline { 2 - 9 } & Low & 19 & 5.0000 & 2.66667 & & & \\
\hline
\end{tabular}

An independent $\mathrm{T}$ - test was conducted to examine whether there was a relationship between knowledge of respondents on effects of self-medication and the practice of self medication. The test revealed a statistically significant inverse relationship between the knowledge and practice of self medication $(\mathrm{t}=-2.226 \mathrm{df}=198, \mathrm{P}<0.05)$. Students with low level of knowledge about the effects of self medication reported high practice of self medication $(M=5.00, S D=2.67)$ than did students with high level of knowledge $(M=4.04$, $\mathrm{SD}=1.68)$.

\section{Discussion}

This study assessed the knowledge and practice of self-medication among students of school of nursing in selected schools in Osun State. Two hundred students participated in this study.

The socio-demographic distribution of the respondents revealed that their mean age and the standard deviation were $21.57 \pm 3.08$. Majority of the respondents were within age range of 20-29 years, almost all were Yoruba and majority were females. About two-third were Christians, while half of the respondents were in 200level, the other half were in 300 level.

Mehta and Sharma (2015) found in a study on the knowledge, attitude and practice of selfmedication among medical students in Chitwan Medical College, Bharatpur, Nepal that more than half of the respondent had good knowledge about self-medication regarding definition, adverse effect and different types of drug. In this study however, almost all the respondents had good knowledge about self medication. It is expected that nursing students having spent more than a year in the school should have basic knowledge on pharmacology. On the other hand, this result is at variance with Raut, Vamsi and Rao (2014) in a study evaluating the knowledge, attitude and practice of self-medication among second year BNSc nursing students, the study showed that respondents' knowledge about appropriate self-medication was poor, but knowledge of the benefits and risks of self-medication was adequate.

The result in this study showed that about two-third of the respondents had high level practice of self medication, while a third had low level practice. More than half equally signified that they are willing to practice self-medication whenever the need arises. This could be due to the fact that they are exposed to many drugs in their course of training and have basic understanding of some of these drugs. Similar findings were made by Mehta and Sharma (2015). They found the Prevalence rate of self-medication of one year period seems high i.e. $84 \%$ and $68.25 \%$ in were females. According to Klemenc-Ketiš, Hladnik and Kersni, (2011), self medication is usually considered as first choice remedy for early disease symptoms and is a part of patient's medical behaviour. More so, Ehigiator et al, (2013) observed self-medication as a common practice among group of health workers in Nigeria that included dental, midwifery and nursing students.

On the factors/ reasons for self-medication among nursing students, the study showed that about half of the respondents self-medicate always for reasons such as presence of minor ailments; and having enough knowledge about drugs as a reasons for self-medication, Also, more than forty percent indicated that financial constraint, previous experience, time saving, advertisement and unavailability of health care services are factors that sometimes influence self-medication. This result supports Raut et al (2014) in which respondents found selfmedication to be time-saving, economical, convenient and providing quick relief in common illnesses. Vizhi and Senapathi (2010) also opined that self-medication is influenced by many 
factors such as education, family, society, law, availability of drugs and exposure to advertisements, which agrees with the findings in this study.

In this study, the hypothesis was tested using independent t-test. Independent t-test showed statistically significant inverse relationship existed between the knowledge and practice of self medication among the nursing students $(\mathrm{t}=-2.226, \mathrm{df}=198, \mathrm{P}<0.05)$. Students with low level of knowledge about the effects of self medication reported high practice of self medication $(M=5.00, S D=2.67)$ than did students with high level of knowledge $(M=4.04$, $\mathrm{SD}=1.67)$.

\section{Conclusion}

In conclusion, nursing students were found to have high level of knowledge about medication and effects of self- medication; however, majority of them still indulge in selfmedication practice. Meanwhile, their knowledge significantly influenced their selfmedication practices. Those with high level of knowledge about effects of self medication, have low level of practice of self medication. Meanwhile, it would be safe, if the people who self-medicate, have sufficient knowledge about the dosage, time of intake, side effect on over dose, because lack of information it can cause serious effects.

The following recommendations were made based on the findings in this study.

1. Although, self-medication is recommended to improve the self-care orientation, but this study found high prevalence of self-medication among nursing students with low knowledge about rational drug usage and uncontrolled availability of drugs have led to numerous healthcare issues. There is an urgent requirement to control the drugs available in the market.

2. Strict laws, control over misguiding advertisements and previous experience as this is one of the factors identified by nursing students, hence healthcare education to all is imperative.

3. The use of drugs as self-medication is mostly due to previous prescriptions, education on proper knowledge about drugs and the associated adverse effects is essential for nursing students, the communities and the healthcare providers at large.

\section{References}

[1]. Al-Hussaini M, Mustafa S, and Ali S. (2014). Self-medication among Undergraduate Medical Students in Kuwait with reference to the Role of the Pharmacist. Journal of Research Pharmacy Practice; 3 (1): 23-27.

[2]. Ali S. E., Ibrahim M. I. M., and Palaian S. (2010). Medication storage and self-medication behaviour amongst female students in Malaysia. Pharmacy Practice; 8(4): 1-7.

[3]. Arikpo G., Eja M., and Enyi-Idoh K. (2009). Self-Medication in Rural Africa. The Internet Journal of Health: 11 (1).

[4]. Auta A., Shalkur D., Omale S. and Abiodun A. H. (2012). Medicine Knowledge and SelfMedication Practice Among Students. JPRD; 4 (1): 6-11.

[5]. Awosusi and Konwea (2015). Self-medication Practice among Secondary School Students in Ekiti State, Southwest Nigeria. JAMPS, 3(2): 61-68.

[6]. Banerjee I, and Bhadury T. (2012). Self-Medication Practice among Undergraduate Medical Students in a tertiary care medical college, West Bengal. J. Postgrad. Med. 58(2):127.

[7]. Bernal B. S. R., and Silva N. N., (2010). Self-Medication in Low-Income Adults in South-Eastern Brazil. Rev SauePulica; 44(6): 1-6.

[8]. Dimabayao C. G. and Mohammad E. K. (2016). Prevalence of Self Medication Practice among Nursing Students in Jazan University, Kingdom of Saudi Arabia. IOSR-JNHS; 5 (1): 11-16

[9]. Ehigiator O., Azodo C.C., Ehizele A.O., Ezeja E.B, Ehigiator L, et al (2013). Self medication practices among dental, mid- wifery and nursing students. Eur J Gen Dentistry 2:54-57.

[10]. El-Nimr, N.A., Wahdan, I.M.H, Wahdan, A.M.H. and Kotb R.E. (2015) Self-medication with drugs and complementary and alternative medicines in Alexandria, Egypt: prevalence, patterns and determinants. East Mediterr Health J.; 21(4):256-65. 
Texila International Journal of Public Health

Volume 4, Issue 4, Dec 2016

[11]. Emmanuel A., Daniel G., Achema G., Afor B., Onyejekwe G., and Gimba SM. (2011). SelfMedication practice among undergraduate nursing students of University of Jos, Nigeria. Nigerian Journal of Pharmaceutical Sciences; 10 (2): 22-26.

[12]. Fadare J. O. and Tamuno I. (2011). Antibiotic Self-Medication among University Medical undergraduates in Northern Nigeria. J Public Health Epidemiol; 3 (5): 217-220.

[13]. Galato D, Galafassi L, Alano GM, and Trauthman SC. (2009). Responsible Self- Medication: Review of the process of Pharmaceutical Attendance. Brazilian Journal of Pharmaceutical Sciences; 45(4):625-633.

[14]. Joshi M.C., Shalini, and Agarwal S. (2011). A questionnaire based study of self-medication practices among young population. Res. J. Pharm., Biol. Chem. Sci.; 2:761-6.

[15]. Lukovic J. A., Miletic V., Pekmezovic T., Trajkovic G., Ratkovic N., et al. (2014). SelfMedication Practices and Risk Factors for Self- Medication among Medical Students in Belgrade, Serbia. PLoS ONE 9(12): e114644. doi:10.1371/ journal.pone.0114644

[16]. Olayemi O. J., Olayinka B. O., Musa A. J., (2010). Evaluation of antibiotic self-medication: Pattern amongst undergraduate students of ABU (Main Campus) Zaria. J Appl Science Res.; 2(1):3538.

[17]. Osemene K. P., Lamikara A. (2012). A study of the prevalence of self-medication practice among University Students in Southwestern Nigeria. Trop J Pharmaceutical Res. 11(4): 683-689

[18]. Shah A.P, Parmar S.A, Kumkishan A, Mehta A.A. (2011). Knowledge, Attitude and Practice (KAP) Survey Regarding the safe use of Medicines in rural area of Gujurat. Adv Trop Med Pub Health; 1(2): 66-70.

[19]. Sontakke S.D., Bajait C.S., Pimpalkhute S.A., Jaiswal K.M, Jaiswal SR. (2011). Comparative study of evaluation of self medication practices in first and third year medical students. Int J Biol Med Res.; 2(2): 561-564.

[20]. Talevi A. (2010). The New Patient and Responsible Self-Medication Practices: A Critical review. Current Drug Safety;

[21]. 5(4):342-53.

[22]. Verma RK, Mohan L \& Pandey M. (2010). Evaluation of self medication among professional student in north India: proper statutory drug control must be implemented. Asian J pharmaclinReas; 3 : 60-64.

[23]. Vizhi S. K., Senapathi R., (2010). Evaluation of the perception, attitude and practice of selfmedication among business students in 3 select Cities, South India. International Journal of Enterprise and Innovation Management Studies (IJEIMS); 1 (3): 40-4.

[24]. World Medical Association (2012). WMA Statement on Self-medication; Re-afffirmed by the $191^{\text {st }}$ WMA Council Session, Prague, Czech Republic, April, 2012. World Medical Association, Inc.

[25]. World Health Organization (2014). Essential Medicines and Health Products. Information Portal; 2014. Geneva, WHO. 